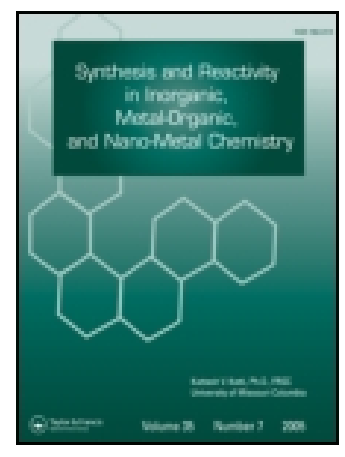

Synthesis and Reactivity in Inorganic and Metal-Organic Chemistry

\title{
KINETICS AND MECHANISM OF RUTHENIUM(III) CATALYZED OXIDATION OF SECONDARY ALCOHOLS BY BROMAMINE-T IN HYDROCHLORIC ACID SOLUTIONS
}

\author{
Puttaswamy , R. Ramachandrappa \& N. M. Made Gowda
}

To cite this article: Puttaswamy , R. Ramachandrappa \& N. M. Made Gowda (2002) KINETICS AND MECHANISM OF RUTHENIUM(III) CATALYZED OXIDATION OF SECONDARY ALCOHOLS BY BROMAMINE-T IN HYDROCHLORIC ACID SOLUTIONS, Synthesis and Reactivity in Inorganic and Metal-Organic Chemistry, 32:7, 1263-1280

To link to this article: http://dx.doi.org/10.1081/SIM-120014302

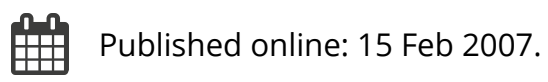

Submit your article to this journal $\sqsubset$

\section{щ Article views: 26}

View related articles $₫$

Citing articles: 2 View citing articles $\square$ 


\title{
KINETICS AND MECHANISM OF RUTHENIUM(III) CATALYZED OXIDATION OF SECONDARY ALCOHOLS BY BROMAMINE-T IN HYDROCHLORIC ACID SOLUTIONS
}

\author{
Puttaswamy, ${ }^{1}$ R. Ramachandrappa, ${ }^{1}$ and N. M. Made \\ Gowda $^{2, *}$ \\ ${ }^{1}$ Department of Post-Graduate Studies in Chemistry, \\ Central College, Bangalore University, \\ Bangalore - 560 001, India \\ ${ }^{2}$ Department of Chemistry, Western Illinois University, \\ 1 University Circle, Macomb, IL 61455, USA
}

\begin{abstract}
The kinetics of oxidation of 2-propanol, 2-butanol, 2-pentanol, 2-hexanol, and 2-heptanol by sodium $N$-bromo- $p$-toluenesulfonamide (bromamine-T or BAT) to the corresponding ketones in the presence of $\mathrm{HCl}$ and catalyzed by rutheniu$\mathrm{m}$ (III) chloride has been studied at $30{ }^{\circ} \mathrm{C}$. The reaction rate shows a first-order dependence on [BAT] and a fractionalorder each on [alcohol], $[\mathrm{Ru}(\mathrm{III})]$ and $\left[\mathrm{H}^{+}\right]$. Addition of the reaction product, $p$-toluenesulfonamide, retards the rate. An increase in the dielectric constant of the medium decreases the
\end{abstract}

*Corresponding author. E-mail: GN-Made@wiu.edu 
rate. Variations of ionic strength and halide ion concentration have no effect on the rate. Rate studies in $\mathrm{D}_{2} \mathrm{O}$ medium show that the solvent isotope effect, $\mathrm{k}_{\left(\mathrm{H}_{2} \mathrm{O}\right)}^{\prime} / \mathrm{k}_{\left(\mathrm{D}_{2} \mathrm{O}\right)}^{\prime}$, equals 0.67 . Proton inventory studies were carried out using $\mathrm{H}_{2} \mathrm{O}-\mathrm{D}_{2} \mathrm{O}$ mixtures. Attempts have been made to arrive at a linear freeenergy relationship through the Taft treatment and observed that the rate constants do not correlate satisfactorily. An isokinetic relationship is observed with $\beta=354 \mathrm{~K}$ indicating that enthalpy factors control the rate which is also confirmed by the Exner criterion. A mechanism consistent with the observed kinetics has been proposed and discussed.

\section{INTRODUCTION}

Considerable attention has centered around the chemistry of $N$-metallo- $N$-haloarylsulfonamides, generally known as organic halomines, because of their versatility in behaving as mild oxidants, halogenating agents, and $\mathrm{N}$-anions. The important chlorine compound of this class, chloramine-T (CAT), which is a by-product in the saccharin manufacture, is a well-known reagent for the determination of diverse substrates. ${ }^{[1]}$ Mechanistic aspects of many of these reactions have been documented.$^{[1,2]}$ The bromine analogue, bromamine- $\mathrm{T}\left(p-\mathrm{CH}_{3} \mathrm{C}_{6} \mathrm{H}_{4} \mathrm{SO}_{2} \mathrm{NBrNa} \cdot 3 \mathrm{H}_{2} \mathrm{O}\right.$ or $\mathrm{BAT}$ ), which can be prepared by the bromination of CAT, is found to be a better oxidizing agent than CAT. However, there is less information available in the literature on BAT. ${ }^{[3,4]}$ The oxidation of secondary alcohols to ketones by the conventional mild to strong oxidants has been reviewed. ${ }^{[5,6]}$ Investigations employing halogen compounds as oxidants include the work of Thiagarajan and Venkatasubramanian ${ }^{[7]}$ and Natarajan and Thiagarajan ${ }^{[8]}$ with aqueous $\mathrm{N}$-bromosuccinamide and $\mathrm{N}$-chlorosuccinamide, respectively. Negi and Banerji, ${ }^{[9]}$ who oxidized a number of secondary alcohols using N-bromoacetamide in acid solutions, concluded that the reaction is governed by a combination of polar and steric effects operating at the carbon center bearing the hydroxyl group. Devi et al ${ }^{[10]}$ oxidized several aliphatic secondary alcohols by pyridinium bromide perbromide in aqueous acetic acid medium and found no structure-reactivity correlations. Ramachandra et al. ${ }^{[1]}$ studied the oxidation of six parasubstituted phenethyl alcohols with CAT in the presence of hydrochloric acid and observed a first-order dependence each on $[\mathrm{CAT}]$ and $\left[\mathrm{H}^{+}\right]$and a fractional-order dependence each on [alcohol] and [chloride ion]. The reaction of secondary alcohols with $\mathrm{N}$-haloamines are sluggish in the 
absence of catalysts. After several catalysts were examined, $\mathrm{RuCl}_{3}$ was found to be an excellent catalyst for the oxidation of secondary alcohols. To throw some light on the mechanism of BAT oxidation, we describe here the detailed kinetics of oxidation of secondary alcohols, namely, 2-propanol, 2butanol, 2-pentanol, 2-hexanol and 2-heptanol, by BAT in the presence of $\mathrm{HCl}$ and $\mathrm{RuCl}_{3}$ at $30{ }^{\circ} \mathrm{C}$. An attempt has been made to identify the most probable reactive species of the oxidant in aqueous acid solution. Attempts have been made to arrive at a linear free-energy relationship through the Taft treatment. An isokinetic relationship has also been deduced with the computed activation parameters.

\section{EXPERIMENTAL}

Bromanine-T was obtained by partial debromination of dibromamine-T (DBT) in $4.0 \mathrm{M} \mathrm{NaOH} \cdot{ }^{[12]}$ The authenticity of the product was confirmed by checking the halogen content iodometrically and then through its mass spectrum, UV, IR and FT-NMR $\left({ }^{1} \mathrm{H}\right.$ and $\left.{ }^{13} \mathrm{C}\right)$ spectral data.${ }^{[13]}$ Aqueous solutions of BAT were prepared, standardized by the iodometric method, ${ }^{[12]}$ and preserved in amber-colored bottles until use to prevent the photochemical deterioration. The alcohols, 2-propanol (IDPL, India), 2-butanol (M\&B, England), 2-pentanol (Riedel, Germany), 2-hexanol and 2-heptanol (Wils Lab, India) were further purified by distillation. Fresh aqueous solutions of alcohols were prepared whenever required. A solution of $\mathrm{RuCl}_{3}$ (Arora Mathey, India), prepared in $0.50 \mathrm{M} \mathrm{HC1}$, was used as the catalyst. Allowance was made for the amount of acid present in the catalyst solution while preparing the solutions of kinetic runs. Solvent isotope studies were made with $\mathrm{D}_{2} \mathrm{O}(99.4 \%)$ supplied by the Bhabha Atomic Research Centre, Mumbai, India. All other reagents were of analytical grades. Triple distilled water was used in the preparation of all aqueous solutions. Regression analysis of the experimental data was carried out using an EC-72 Statistical Calculator.

\section{Kinetic Meaurements}

Kinetic runs were performed under pseudo-first-order conditions with a known excess of [alcohol $]_{0}$ over $[\mathrm{BAT}]_{0}$. The reactions were carried out in stoppered Pyrex boiling tubes whose outer surface was coated black to eliminate photochemical effects. Solutions containing appropriate amounts of alcohol, $\mathrm{HCl}, \mathrm{RuCl}_{3}, \mathrm{NaClO}_{4}$, and water (to keep the total volume constant for all runs) were placed in the tube and thermostatted at $30{ }^{\circ} \mathrm{C}$ for 
about $30 \mathrm{~min}$. A measured amount of BAT solution, also thermostatted at the same temperature, was rapidly added to the mixture, which was shaken intermittently for uniform concentration. The progress of the reaction was monitored by withdrawing known aliquots $(5.0 \mathrm{~mL}$ each) of the reaction mixture at regular time intervals and iodometrically determining the unreacted BAT. The course of the reaction was studied up to two half-lives. The psuedo-first-order rate constants, $\mathrm{k}^{\prime}$, calculated from linear plots of $\log [\mathrm{BAT}]$ vs. time were reproducible within an error of $\pm 2-3 \%$.

\section{Reaction Stoichiometry}

Various ratios of the alcohol-to-BAT were equilibrated in the presence of $1.00 \times 10^{-2} \mathrm{M} \mathrm{HCl}$ and $4.82 \times 10^{-5} \mathrm{M} \mathrm{RuCl}_{3}$ for $24 \mathrm{~h}$ at $30{ }^{\circ} \mathrm{C}$ under the condition $[\mathrm{BAT}]_{0} \gg[\text { alcohol }]_{0}$. Determination of unreacted BAT in the reaction mixture showed that one mole of the alcohol consumed one mole of BAT, confirming the following stoichiometry:

$$
\mathrm{R}-\mathrm{CH}(\mathrm{OH}) \mathrm{CH}_{3}+\mathrm{ArNBrNa} \longrightarrow \mathrm{R}-\mathrm{C}(\mathrm{O}) \mathrm{CH}_{3}+\mathrm{ArNH}_{2}+\mathrm{Na}^{+}+\mathrm{Br}^{-}
$$

where $\mathrm{R}=\mathrm{CH}_{3}$ for 2-propanol, $\mathrm{CH}_{3} \mathrm{CH}_{2}$ for 2-butanol, $\mathrm{CH}_{3}\left(\mathrm{CH}_{2}\right)_{2}$ for 2pentanol, $\mathrm{CH}_{3}\left(\mathrm{CH}_{2}\right)_{3}$ for 2-hexanol, and $\mathrm{CH}_{3}\left(\mathrm{CH}_{2}\right)_{4}$ for 2-heptanol and $\mathrm{Ar}=p-\mathrm{CH}_{3} \mathrm{C}_{6} \mathrm{H}_{4} \mathrm{SO}_{2}$.

\section{Product Analysis}

The ketones, which are oxidation products of secondary alcohols, were identified by their 2,4-dinitrophenylhydrazone $(2,4-\mathrm{DNP})$ derivatives. $^{[14]}$ These derivatives were recrystallized from EtOH and their melting points were found to be identical with the DNP derivatives of the corresponding authentic ketones. ${ }^{[14]}$ These data are presented in Table I. The reduction product of BAT, $p$-toluenesulfonamide $\left(\mathrm{ArNH}_{2}\right)$, was recrystallized from dichloromethane/petroleum ether $(1: 1 \mathrm{v} / \mathrm{v})$ and identified [m.p. $=137-140{ }^{\circ} \mathrm{C} ;$ TLC: $\mathrm{R}_{\mathrm{f}}=0.34, \mathrm{CH}_{2} \mathrm{Cl}_{2}-\mathrm{CHCl}_{3}$ mixture, $7: 3 \mathrm{v} / \mathrm{v}$, iodine as developing reagent]. 
Table I. Melting Points of 2,4-DNP Derivatives of Oxidation Products of Secondary Alcohols

\begin{tabular}{lccc}
\hline & & \multicolumn{2}{c}{ Melting Points of $2,4-D N P$ Derivatives $\left({ }^{\circ} \mathrm{C}\right)$} \\
\cline { 3 - 4 } Alcohol & Corresponding Ketone & Experimental & Literature $^{[14]}$ \\
\hline 2-propanol & acetone & $127-128$ & 128 \\
2-butanol & 2-butanone & $115-116$ & 115 \\
2-pentanol & 2-pentanone & $142-143$ & 144 \\
2-hexanol & 2-hexanone & $106-107$ & 107 \\
2-heptanol & 2-heptanone & $89-90$ & 88 \\
\hline
\end{tabular}

\section{RESULTS AND DISCUSSION}

\section{Effects of Reactants on the Rate}

With the substrate in excess at constant $[\text { alcohol }]_{0},[\mathrm{HCl}],\left[\mathrm{RuCl}_{3}\right]$ and temperature, plots of $\log [\mathrm{BAT}] v s$. time were linear $(\mathrm{r}>0.9902)$, indicating a first-order dependence on the rate on [BAT]. Values of pseudo-first-order rate constants $\left(\mathrm{k}^{\prime}\right)$ are given in Table II. These $\mathrm{k}^{\prime}$ values were unaffected by the variation in $[\mathrm{BAT}]_{0}$, confirming the first-order dependence on [oxidant $]_{0}$. Under the same experimental conditions, an increase in [alcohol $]_{0}$ increased

Table II. Effects of the Reactant Concentrations on the Reaction Rate

\begin{tabular}{|c|c|c|c|c|c|c|}
\hline \multirow{2}{*}{$\begin{array}{l}{[\mathrm{BAT}]_{0}} \\
\times 10^{4} \\
(\mathrm{M})\end{array}$} & \multirow{2}{*}{$\begin{array}{c}{[\text { Alcohol }]_{0}} \\
\times 10^{2} \\
(\mathrm{M})\end{array}$} & \multicolumn{5}{|c|}{$\mathrm{k}^{\prime} \times 10^{3}\left(\mathrm{~s}^{-1}\right)$} \\
\hline & & 2-Propanol & 2-Butanol & 2-Pentanol & 2-Hexanol & 2-Heptanol \\
\hline 2.00 & 1.00 & 1.54 & 3.30 & 3.10 & 2.65 & 2.50 \\
\hline 4.00 & 1.00 & 1.58 & 3.26 & 2.96 & 2.76 & 2.60 \\
\hline 6.00 & 1.00 & 1.50 & 3.35 & 3.05 & 2.80 & 2.55 \\
\hline 8.00 & 1.00 & 1.42 & 3.42 & 2.90 & 2.82 & 2.62 \\
\hline 10.00 & 1.00 & 1.46 & 3.48 & 3.12 & 2.72 & 2.46 \\
\hline 12.00 & 1.00 & 1.52 & 3.38 & 3.08 & 2.88 & 2.40 \\
\hline 6.00 & 0.500 & 1.04 & 2.10 & 1.84 & 1.62 & 1.75 \\
\hline 6.00 & 1.00 & 1.50 & 3.35 & 3.05 & 2.80 & 2.55 \\
\hline 6.00 & 2.00 & 2.16 & 4.75 & 4.80 & 4.35 & 3.80 \\
\hline 6.00 & 3.00 & 2.65 & 6.10 & 6.35 & 5.68 & 4.90 \\
\hline 6.00 & 4.00 & 3.08 & 7.28 & 7.48 & 6.85 & 5.62 \\
\hline 6.00 & 5.00 & 3.42 & 8.30 & 8.70 & 7.90 & 6.25 \\
\hline
\end{tabular}

${ }^{\mathrm{a}}[\mathrm{HCl}]=1.00 \times 10^{-2} \mathrm{M} ;[\mathrm{Ru}(\mathrm{III})]=4.82 \times 10^{-5} \mathrm{M} ; \mathrm{I}=0.30 \mathrm{M} ; \mathrm{Temp} .=30^{\circ} \mathrm{C}$. 
the $\mathrm{k}^{\prime}$ value (Table II). Plots of $\log \mathrm{k}^{\prime}$ vs. $\log [\text { alcohol }]_{0}$ were linear $(\mathrm{r}>0.9930)$ with fractional slopes $(0.50-0.70)$, showing a fractional-order dependence of the rate on [alcohol].

\section{Effect of $[\mathrm{HCl}]$ on the Rate}

The rate increased with an increase in [HCl] (Table III) and plots of $\log \mathrm{k}^{\prime} \quad$ vs. $\log [\mathrm{HCl}]$ were linear $(\mathrm{r}>0.9915)$ with fractional slopes $(0.50-0.80)$, showing a fractional-order dependence of the rate on $[\mathrm{HCl}]$.

\section{Effect of $\left[\mathrm{H}^{+}\right]$on the Rate}

At total constant $\left[\mathrm{Cl}^{-}\right]$of $0.06 \mathrm{M}$, maintained by adding $\mathrm{NaCl}$, the concentration of $\mathrm{H}^{+}$was varied using $\mathrm{HCl}$. The rate increased with increase in $\left[\mathrm{H}^{+}\right]$(values are not shown). Plots of $\log \mathrm{k}^{\prime}$ vs. $\log \left[\mathrm{H}^{+}\right]$were linear $(\mathrm{r}>0.9946)$ with fractional slopes $(0.50-0.80)$, showing a fractional-order in $\left[\mathrm{H}^{+}\right]$.

\section{Effect of Halide Ions on the Rate}

At constant $\left[\mathrm{H}^{+}\right]$of $0.010 \mathrm{M}$ maintained with $\mathrm{HCl}$, addition of $\mathrm{NaCl}$ did not affect the rate. Hence, the dependence of the rate on $[\mathrm{HCl}]$ reflected

Table III. Effects of $\mathrm{HCl}$ and $\mathrm{Ru}(\mathrm{III})$ Concentrations on the Reaction Rate ${ }^{\mathrm{a}}$

\begin{tabular}{lcccccc}
\hline$[\mathrm{HCl}]$ & {$[\mathrm{Ru}(\mathrm{III})]$} & \multicolumn{5}{c}{$\mathrm{k}^{\prime} \times 10^{3}\left(\mathrm{~s}^{-1}\right)$} \\
$\times 10^{2}$ & $\times 10^{5}$ & \multicolumn{5}{c}{} \\
\cline { 3 - 7 }$(\mathrm{M})$ & $(\mathrm{M})$ & 2-Propanol & 2-Butanol & 2-Pentanol & 2-Hexanol & 2-Heptanol \\
\hline 0.50 & 4.82 & 1.04 & 2.10 & 1.90 & 1.85 & 1.82 \\
1.00 & 4.82 & 1.50 & 3.35 & 3.05 & 2.80 & 2.55 \\
2.00 & 4.82 & 2.16 & 5.20 & 4.55 & 4.05 & 3.65 \\
3.00 & 4.82 & 2.75 & 6.94 & 5.70 & 5.25 & 4.70 \\
4.00 & 4.82 & 3.15 & 8.80 & 6.95 & 6.10 & 5.45 \\
5.00 & 4.82 & 3.52 & 10.2 & 8.00 & 6.98 & 6.08 \\
1.00 & 1.96 & 0.81 & 2.15 & 1.80 & 1.66 & 1.54 \\
1.00 & 2.52 & 0.98 & 2.46 & 2.14 & 1.91 & 1.75 \\
1.00 & 3.64 & 1.24 & 2.82 & 2.48 & 2.34 & 2.10 \\
1.00 & 4.82 & 1.50 & 3.35 & 3.05 & 2.80 & 2.55 \\
1.00 & 7.24 & 1.86 & 3.82 & 3.66 & 3.38 & 3.05 \\
1.00 & 9.26 & 2.10 & 4.30 & 4.18 & 3.95 & 3.54 \\
\hline
\end{tabular}

${ }^{\mathrm{a}}[\mathrm{BAT}]_{0}=6.00 \times 10^{-4} \mathrm{M} ;[\text { alcohol }]_{0}=1.00 \times 10^{-2} \mathrm{M} ; \mathrm{I}=0.30 \mathrm{M} ;$ Temp. $=30^{\circ} \mathrm{C}$. 
the effect of $\left[\mathrm{H}^{+}\right]$only on the reaction. Similarly, addition of $\mathrm{Br}^{-}$ions in the form of $\mathrm{NaBr}\left(5.0 \times 10^{-4}\right.$ to $\left.3.0 \times 10^{-3} \mathrm{M}\right)$ had no effect on the rate.

\section{Effect of $\left[\mathrm{RuCl}_{3}\right]$ on the Rate}

The rate increased with an increase in $\left[\mathrm{RuCl}_{3}\right]$ (Table III). Plots of $\log \mathrm{k}^{\prime}$ vs. $\log \left[\mathrm{RuCl}_{3}\right]$ were linear with fractional slopes $(0.40-0.60)$, showing a fractional-order dependence on $\left[\mathrm{RuCl}_{3}\right]$.

\section{Effect of $p$-Toluenesulfonamide (PTS) on the Rate}

Addition of PTS to the reaction mixture decreased the rate (Table IV). Plots of $\log \mathrm{k}^{\prime}$ vs. $\log [\mathrm{PTS}]$ were linear $(\mathrm{r}>0.9958)$ with negative slopes (0.30-0.40), showing a negative fractional-order on [PTS]. It indicates that PTS is involved in a fast pre-equilibrium to the rate-limiting step.

\section{Effect of Varying Dielectric Constant (D) of the Medium on the Rate}

The dielectric constant of the medium was varied by adding $\mathrm{MeOH}$ $(0-40 \% \mathrm{v} / \mathrm{v})$ to the reaction mixture. The rate decreased with increase in $\mathrm{MeOH}$ content (Table V). Plots of $\log \mathrm{k}^{\prime}$ vs. $1 / \mathrm{D}$ were linear $(\mathrm{r}>0.9890)$ with negative slopes supporting a rate-limiting step with partial ionization. Control experiments with $\mathrm{MeOH}$, however, showed that there is a slight decomposition of the solvent under experimental conditions (e.g., for the

Table IV. Effect of $p$-Toluenesulfonamide (PTS) on the Reaction Rate ${ }^{\mathrm{a}}$

\begin{tabular}{lccccc}
\hline & \multicolumn{5}{c}{$\mathrm{k}^{\prime} \times 10^{3}\left(\mathrm{~s}^{-1}\right)$} \\
\cline { 2 - 6 }$(\mathrm{PTS}] \times 10^{4}$ & 2-Propanol & 2-Butanol & 2-Pentanol & 2-Hexanol & 2-Heptanol \\
\hline 0.0 & 1.50 & 3.35 & 3.05 & 2.80 & 2.55 \\
5.00 & 1.45 & 3.20 & 2.92 & 2.62 & 2.48 \\
10.00 & 1.18 & 2.45 & 2.25 & 2.10 & 2.10 \\
15.00 & 0.98 & 2.10 & 1.90 & 1.75 & 1.78 \\
20.00 & 0.90 & 1.88 & 1.68 & 1.56 & 1.64 \\
30.00 & 0.80 & 1.60 & 1.45 & 1.32 & 1.42 \\
\hline
\end{tabular}

${ }^{\mathrm{a}}[\mathrm{BAT}]_{0}=6.00 \times 10^{-4} \mathrm{M} ;[\text { alcohol }]_{0}=1.00 \times 10^{-2} \mathrm{M} ;[\mathrm{HCl}]=1.00 \times 10^{-2} \mathrm{M} ;[\mathrm{Ru}(\mathrm{III})]=$ $4.82 \times 10^{-5} \mathrm{M} ; \mathrm{I}=0.30 \mathrm{M}$; Temp. $=30^{\circ} \mathrm{C}$. 
Table V. Effect of the Dielectric Constant (D) on the Reaction Rate ${ }^{\mathrm{a}}$

\begin{tabular}{lcccccc}
\hline & & \multicolumn{5}{c}{$\mathrm{k}^{\prime \mathrm{c}} \times 10^{3}\left(\mathrm{~s}^{-1}\right)$} \\
\cline { 3 - 7 } $\begin{array}{l}\text { \% MeOH } \\
\mathrm{v} / \mathrm{v})\end{array}$ & $\mathrm{D}^{\mathrm{b}}$ & 2-Propanol & 2-Butanol & 2-Pentanol & 2-Hexanol & 2-Heptanol \\
\hline 0 & 76.73 & $1.50(0.00)$ & $3.35(0.00)$ & $3.05(0.00)$ & $2.80(0.00)$ & $2.55(0.00)$ \\
10 & 72.37 & $1.38(0.02)$ & $2.92(0.02)$ & $2.50(0.02)$ & $2.32(0.02)$ & $2.20(0.02)$ \\
20 & 67.48 & $1.26(0.03)$ & $2.40(0.03)$ & $1.95(0.03)$ & $1.90(0.03)$ & $1.86(0.03)$ \\
30 & 62.71 & $1.15(0.03)$ & $1.96(0.03)$ & $1.58(0.03)$ & $1.52(0.03)$ & $1.55(0.03)$ \\
40 & 56.06 & $1.04(0.03)$ & $1.55(0.03)$ & $1.18(0.03)$ & $1.22(0.03)$ & $1.24(0.03)$ \\
\hline
\end{tabular}

${ }^{\mathrm{a}}[\mathrm{BAT}]_{0}=6.00 \times 10^{-4} \mathrm{M} ;[\text { alcohol }]_{0}=1.00 \times 10^{-2} \mathrm{M} ;[\mathrm{HCl}]=1.00 \times 10^{-2} \mathrm{M} ;[\mathrm{Ru}(\mathrm{III})]=$ $4.82 \times 10^{-5} \mathrm{M} ; \mathrm{I}=0.30 \mathrm{M}$; Temp. $=30^{\circ} \mathrm{C}$.

${ }^{\mathrm{b}} \mathrm{D}$ values are from: Akerlof, G. Dielectric Constants of Some Organic Solvent-Water Mixtures at Various Temperatures. J. Amer. Chem. Soc. 1932, 54, 4125-4139; Parsons, R. Hand Book of Electrochemical Constants; Butterworths Scientific Publications: London, 1959; 11.

${ }^{c} \mathrm{k}^{\prime}$ values in parentheses are from control experiments with $10-40 \% \mathrm{MeOH}$ : [BAT] $]_{0}=$ $6.00 \times 10^{-4} \mathrm{M}$, [secondary alcohol $]_{0}=0.0 \mathrm{M} ;[\mathrm{HCl}]=1.00 \times 10^{-2} \mathrm{M} ;[\mathrm{Ru}(\mathrm{III})]=4.82 \times$ $10^{-5} \mathrm{M} ; \mathrm{I}=0.30 \mathrm{M}$; Temp. $=30^{\circ} \mathrm{C}$.

control experiment with $40 \% \mathrm{MeOH}$ in the solvent and the reaction mixture without the secondary alcohol substrate, the $\mathrm{k}^{\prime}$ value for $\mathrm{MeOH}$ oxidation was only $2.4-2.8 \%$ of the total $\mathrm{k}^{\prime}$ value for the oxidation of secondary alcohol plus $\mathrm{MeOH}$, see data in Table V). This was allowed for in the calculation of the net reaction rate constant for the oxidation of secondary alcohols.

\section{Effect of Ionic Strength on the Rate}

The ionic strength (I) of the reaction system was maintained at a constant high value $(0.30 \mathrm{M})$ using a concentrated solution of sodium perchlorate to swamp the reaction. However, variation of I $(0.10-0.60 \mathrm{M})$ has no effect on the reaction rate indicating that non-ionic species are involved in the rate-limiting step.

\section{Effect of Solvent Isotope on the Rate}

As the reaction rate depends on the hydrogen ion concentration, solvent isotope studies were made using $\mathrm{D}_{2} \mathrm{O}$ with 2-propanol as a probe. The 
Table VI. Proton Inventory Studies for 2-Propanol in $\mathrm{H}_{2} \mathrm{O}-\mathrm{D}_{2} \mathrm{O}$ Mixtures ${ }^{\mathrm{a}}$

\begin{tabular}{lc}
\hline $\begin{array}{l}\text { Atom Fraction of } \\
\text { Deuterium (n) }\end{array}$ & $\mathrm{k}_{\mathrm{n}}^{\prime} \times 10^{3}\left(\mathrm{~s}^{-1}\right)$ \\
\hline 0.000 & 1.50 \\
0.250 & 1.65 \\
0.500 & 1.84 \\
0.753 & 2.02 \\
0.947 & 2.24 \\
\hline${ }^{\mathrm{a}}[\mathrm{BAT}]_{0}=6.00 \times 10^{-4} \mathrm{M} ; \quad[\text { alcohol }]_{0}=1.00 \times 10^{-2} \mathrm{M} ;$ \\
{$[\mathrm{HCl}]=1.00 \times 10^{-2} \mathrm{M} ;[\mathrm{Ru}(\mathrm{III})]=4.82 \times 10^{-5} \mathrm{M} ; \mathrm{I}=$} \\
$0.30 \mathrm{M} ; \mathrm{Temp} .=30^{\circ} \mathrm{C}$.
\end{tabular}

values were $\mathrm{k}^{\prime}\left(\mathrm{H}_{2} \mathrm{O}\right)=1.50 \times 10^{-3} \mathrm{~s}^{-1}$ and $\mathrm{k}^{\prime}\left(\mathrm{D}_{2} \mathrm{O}\right)=2.24 \times 10^{-3} \mathrm{~s}^{-1}$, leading to a solvent isotope effect, $\mathrm{k}^{\prime}\left(\mathrm{H}_{2} \mathrm{O}\right) / \mathrm{k}^{\prime}\left(\mathrm{D}_{2} \mathrm{O}\right)=0.67$. Proton inventory studies were made in $\mathrm{H}_{2} \mathrm{O}-\mathrm{D}_{2} \mathrm{O}$ mixtures with the same probe and the results are shown in Table VI. The corresponding proton inventory plot from the rate constant $\mathrm{k}_{n}^{\prime}$ in a solvent mixture of the deuterium atom fraction $\mathrm{n}$ is given in Fig. 1.

\section{Effect of Temperature on the Rate}

The reaction was studied with varying the temperature $\left(25\right.$ to $\left.40{ }^{\circ} \mathrm{C}\right)$, keeping other experimental conditions constant. From the linear Arrhenius plots of $\log \mathrm{k}^{\prime}$ vs. $1 / \mathrm{T}(\mathrm{r}>0.9892)$ and the Eyring plots of $\log \left(\mathrm{k}^{\prime} / \mathrm{T}\right)$ vs. 1/T $(\mathrm{r}>0.9901)$, the activation parameters $\left(\mathrm{E}_{\mathrm{a}}, \Delta \mathrm{H}^{\neq}\right.$, and $\left.\Delta \mathrm{S}^{\neq}\right)$were computed. The data are summarized in Tables VII and VIII.

\section{Test for Free Radicals}

Alkene monomers such as acrylonitrile and a freshly prepared $10 \%$ acrylamide solution, under nitrogen atmosphere, were added to initiate polymerization in the presence of free radicals formed in situ. A lack of polymerization indicated the absence of free radicals in the reaction mixture. Proper control experiments were also run.

It is expected that similar equilibria exist in aqueous solutions of $\mathrm{N}$-metallo-N-haloarylsulfonamides. ${ }^{[15-18]}$ Bromamine-T acts as an oxidizing agent in both acidic and alkaline solutions. In general, BAT undergoes 


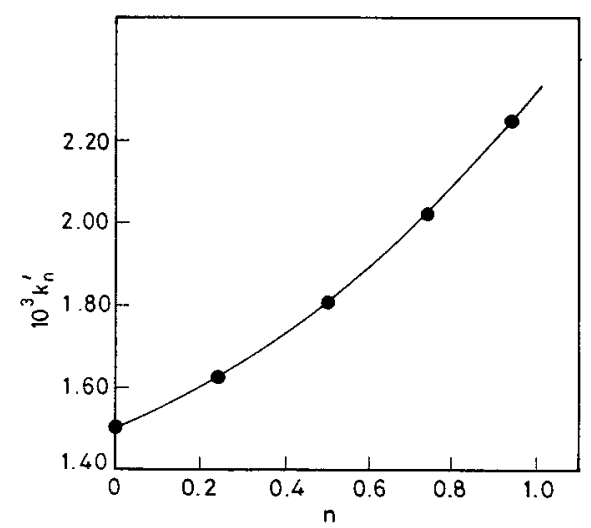

Figure 1. Proton inventory plot of the rate constant $v s$. the deuterium atom fraction in $\mathrm{H}_{2} \mathrm{O}-\mathrm{D}_{2} \mathrm{O}$ mixtures. Experimental conditions are as in Table IV or VI.

Table VII. Effect of the Temperature on the Oxidation of Secondary Alcohols by $\mathrm{BAT}^{\mathrm{a}}$

\begin{tabular}{lcccc}
\hline & \multicolumn{4}{c}{$\mathrm{k}^{\prime} \times 10^{3}\left(\mathrm{~s}^{-1}\right)$} \\
\cline { 2 - 5 } Alcohol & $18 \mathrm{~K}$ & $303 \mathrm{~K}$ & $308 \mathrm{~K}$ & $313 \mathrm{~K}$ \\
\hline 2-propanol & 1.03 & 1.50 & 2.55 & 4.10 \\
2-butanol & 2.54 & 3.35 & 4.95 & 6.70 \\
2-pentanol & 2.02 & 3.05 & 4.15 & 6.25 \\
2-hexanol & 2.08 & 2.80 & 4.60 & 6.80 \\
2-heptanol & 1.70 & 2.55 & 3.88 & 5.75 \\
\hline
\end{tabular}

${ }^{\mathrm{a}}[\mathrm{BAT}]_{0}=6.00 \times 10^{-4} \mathrm{M} ;[\text { alcohol }]_{0}=1.00 \times 10^{-2} \mathrm{M} ;[\mathrm{HCl}]=1.00 \times 10^{-2} \mathrm{M} ;[\mathrm{Ru}(\mathrm{III})]=$ $4.82 \times 10^{-5} \mathrm{M} ; \mathrm{I}=0.30 \mathrm{M}$.

Table VIII. Activation Parameters for the Oxidation of Secondary Alcohols by $\mathrm{BAT}^{\mathrm{a}}$

\begin{tabular}{lccc}
\hline Alcohol & $\mathrm{E}_{\mathrm{a}}(\mathrm{kJ} / \mathrm{mol})$ & $\Delta \mathrm{H}^{\neq}(\mathrm{kJ} / \mathrm{mol})$ & $\Delta \mathrm{S}^{\neq}(\mathrm{J} / \mathrm{Kmol})$ \\
\hline 2-propanol & 72.8 & 70.3 & -67.4 \\
2-butanol & 52.7 & 50.2 & -127 \\
2-pentanol & 56.2 & 53.7 & -116 \\
2-hexanol & 62.9 & 60.4 & -94.7 \\
2-heptanol & 65.4 & 62.9 & -87.2 \\
\hline
\end{tabular}

${ }^{\mathrm{a}}[\mathrm{BAT}]_{0}=6.00 \times 10^{-4} \mathrm{M} ;[\text { alcohol }]_{0}=1.00 \times 10^{-2} \mathrm{M} ;[\mathrm{HCl}]=1.00 \times 10^{-2} \mathrm{M} ;[\mathrm{Ru}(\mathrm{III})]=$ $4.82 \times 10^{-5} \mathrm{M} ; \mathrm{I}=0.30 \mathrm{M}$. 
a two-electron reduction in its reactions. The oxidation potential of $\mathrm{BAT} / \mathrm{ArNH}_{2}$ is $\mathrm{pH}$-dependent and decreases with increase in the $\mathrm{pH}$ of the solution, having values of $1.14 \mathrm{~V}$ at $\mathrm{pH} 0.65$ and $0.50 \mathrm{~V}$ at $\mathrm{pH} 12$. Depending on the $\mathrm{pH}$, BAT furnishes different types of reactive species [Eqs. (2)-(7)] such as $\mathrm{ArNHBr}, \mathrm{ArNBr}_{2}, \mathrm{HOBr}$, and possibly $\mathrm{H}_{2} \mathrm{O}^{+} \mathrm{Br}$ in acid solutions. ${ }^{[16-18]}$

$$
\begin{aligned}
& \mathrm{ArNBrNa} \rightleftharpoons \mathrm{ArNBr}^{-}+\mathrm{Na}^{+} \\
& \mathrm{ArNBr}^{-}+\mathrm{H}^{+} \stackrel{\mathrm{K}_{\mathrm{a}}}{\rightleftharpoons} \mathrm{ArNHBr} \\
& 2 \mathrm{ArNHBr} \stackrel{\mathrm{K}_{\mathrm{d}}}{\rightleftharpoons} \mathrm{ArNBr}_{2}+\mathrm{ArNH}_{2} \\
& \mathrm{ArNHBr}+\mathrm{H}_{2} \mathrm{O} \rightleftharpoons \mathrm{ArNH}_{2}+\mathrm{HOBr} \\
& \mathrm{ArNHBr}+\mathrm{H}^{+} \rightleftharpoons \mathrm{ArN}^{+} \mathrm{H}_{2} \mathrm{Br} \\
& \mathrm{ArN}^{+} \mathrm{H}_{2} \mathrm{Br}+\mathrm{H}_{2} \mathrm{O} \rightleftharpoons \mathrm{ArNH}_{2}+\mathrm{H}_{2} \mathrm{O}^{+} \mathrm{Br}
\end{aligned}
$$

If dibromamine-T $\left(\mathrm{ArNBr}_{2}\right)$ were the reactive species, then the rate law would predict a second-order dependence of the rate on [BAT] [Eq. (4)], which is contrary to the experimental observations. The rate increases with increase in $\left[\mathrm{H}^{+}\right]$but is retarded by the added PTS. Hence, Eqs. (6) and (7) play a dominant role in the oxidation of secondary alcohols by BAT.

A review of aquachloro complex ions of ruthenium(III) shows that several species such as $\left[\mathrm{RuCl}_{6}\right]^{3-},\left[\mathrm{RuCl}_{5}\left(\mathrm{H}_{2} \mathrm{O}\right)\right]^{2-},\left[\mathrm{RuCl}_{4}\left(\mathrm{H}_{2} \mathrm{O}\right)_{2}\right]^{-}$, $\left[\mathrm{RuCl}_{3}\left(\mathrm{H}_{2} \mathrm{O}\right)_{3}\right],\left[\mathrm{RuCl}_{2}\left(\mathrm{H}_{2} \mathrm{O}\right)_{4}\right]^{+},\left[\mathrm{RuCl}\left(\mathrm{H}_{2} \mathrm{O}\right)_{5}\right]^{2+}$, and $\left[\mathrm{Ru}\left(\mathrm{H}_{2} \mathrm{O}\right)_{6}\right]^{3+}$ exist in aqueous solutions of $\left[\mathrm{RuCl}_{3}\right]$. $^{[19-22]}$ The $\left[\mathrm{RuCl}_{6}\right]^{3-}$ complex ion is predominant in high $\mathrm{Cl}^{-}$concentrations. As the number of $\mathrm{Cl}^{-}$ions decreases in the complex, the rate of $\mathrm{Cl}^{-}$ion replacement by $\mathrm{H}_{2} \mathrm{O}$ decreases. ${ }^{[21]}$ Therefore, the aquation of $\left[\mathrm{RuCl}_{6}\right]^{3-}$ to $\left[\mathrm{RuCl}_{5}\left(\mathrm{H}_{2} \mathrm{O}\right)\right]^{2-}$ occurs within seconds while the half-reaction time for conversion of $\left[\mathrm{RuCl}\left(\mathrm{H}_{2} \mathrm{O}\right)_{5}\right]^{2+}$ to $\left[\mathrm{Ru}\left(\mathrm{H}_{2} \mathrm{O}\right)_{6}\right]^{3+}$ is approximately one year. ${ }^{[20-21]}$ Since $\mathrm{RuCl}_{3}$ was dissolved in $0.50 \mathrm{M} \mathrm{HCl}$ and the rate of aquation of $\left[\mathrm{RuCl}_{6}\right]^{3-}$ to $\left[\mathrm{RuCl}_{5}\left(\mathrm{H}_{2} \mathrm{O}\right)\right]^{2-}$ is fast, the active catalyst species may be assumed to be either $\left[\mathrm{RuCl}_{6}\right]^{3-}$ or $\left[\mathrm{RuCl}_{5}\left(\mathrm{H}_{2} \mathrm{O}\right)\right]^{2-}$ ion as shown in the following equilibria [Eqs. (8) and (9)]: 


$$
\begin{aligned}
& \mathrm{RuCl}_{3}+3 \mathrm{HCl} \rightleftharpoons\left[\mathrm{RuCl}_{6}\right]^{3-}+3 \mathrm{H}^{+} \\
& {\left[\mathrm{RuCl}_{6}\right]^{3-}+\mathrm{H}_{2} \mathrm{O} \rightleftharpoons\left[\mathrm{RuCl}_{5}\left(\mathrm{H}_{2} \mathrm{O}\right)\right]^{2-}+\mathrm{Cl}^{-}}
\end{aligned}
$$

Singh et al. ${ }^{[23,24]}$ used the above equilibria in the ruthenium(III) chloride catalyzed oxidation of primary alcohols by BAT and of glycols by $\mathrm{N}$-bromoacetamide in $\mathrm{HClO}_{4}$ solutions. In the present study, however, the zero effect of chloride ion on the rate indicates that the second equilibrium [Eq. (9)] does not play a role in the reaction and, hence, the complex ion, $\left[\mathrm{RuCl}_{6}\right]^{3-}$, is assumed to be the reactive catalyst species.

Ultraviolet spectral measurements showed that the alcohol solution had a sharp absorption band at $241 \mathrm{~nm}$ while bands around 204 and $224 \mathrm{~nm}$ were noticed for $\mathrm{Ru}(\mathrm{III})$ and BAT solutions, respectively, in the presence of $0.1 \mathrm{M} \mathrm{HCl}$. The mixtures of (i) alcohol $+\mathrm{Ru}(\mathrm{III})$ and (ii) BAT $+\mathrm{Ru}$ (III) in the presence of $0.1 \mathrm{M} \mathrm{HCl}$ showed no change in $\lambda_{\max }$. But when BAT and alcohol solutions were mixed in the presence of $0.1 \mathrm{M} \mathrm{HCl}$, a single sharp absorption band appeared at $210 \mathrm{~nm}$ indicating an intermediate formation between BAT and alcohol. Based on the preceding discussion, a general mechanism (Fig. 2) is proposed for the $\mathrm{RuCl}_{3}$ catalyzed oxidation of secondary alcohols by BAT to account for the observed kinetics.

Gopalakrishnan and Hogg ${ }^{[25]}$ have investigated the mechanism of Nbromosuccinimide (NBS)-promoted oxidative decarboxylation of glycine, alanine, and valine in acid buffer solutions using NBS as the source of positive bromine, $\mathrm{Br}^{+}$, species. Other groups, which studied the oxidative degradation of amino acids and their derivatives including peptides using NBS, ${ }^{[26-27]}$ contend that the dipolar NBS molecule acts through its positive-bromine end in these reactions. Since the nitrogen of NBS is protonated in acid solutions, formation of $\mathrm{Br}^{+}$and its solvation will result in the production of protonated hypobromous acid, $\mathrm{H}_{2} \mathrm{O}^{+} \mathrm{Br}$, which is considered as the active species responsible for oxidizing $\alpha$-amino acids and their derivatives. ${ }^{[25,26]}$ Hardy and Johnston, ${ }^{[17]}$ who have studied the kinetics of the reaction of p-nitrophenoxide ion with bromamine-B (BAB) in dilute alkaline solution, have shown that $\mathrm{BAB}$ acts via formation of polar positive bromine-containing intermediates, $\mathrm{HOBr}$ and $\mathrm{OBr}^{-}$. In a similar way, the oxidant BAT used in the present study, which contains a polar $\mathrm{N}-\mathrm{Br}$ bond as the source of positive bromine, $\mathrm{Br}^{+}$, species, forms the conjugate acid, ArNHBr, in acid solutions [Eq. (3)]. In the scheme of Fig. 2, ArNHBr with its polar $\mathrm{N}-\mathrm{Br}$ bond intact interacts with $\mathrm{H}_{3} \mathrm{O}^{+}$to form the reactive oxidant species, $\mathrm{H}_{2} \mathrm{O}^{+} \mathrm{Br}$, and the parent sulfonamide, $\mathrm{ArNH}_{2}$, in a fast equilibrium step (i). This step (i) supports the fractional-order dependence on $\left[\mathrm{H}^{+}\right]$ and the negative fractional-order dependence on $\left[\mathrm{ArNH}_{2}\right]$ observed 


$$
\begin{array}{rlrl}
\mathrm{ArNHBr}+\mathrm{H}_{3} \mathrm{O}^{+} & \stackrel{\mathrm{K}_{1}}{\rightleftharpoons} \underset{\mathrm{K}_{2}}{\mathrm{ArNH}_{2}+\mathrm{H}_{2} \mathrm{O}^{+} \mathrm{Br}} & \text { fast (i) } \\
\text { alcohol }+\mathrm{H}_{2} \mathrm{O}^{+} \mathrm{Br} & \underset{\text { (intermediate) }}{\mathrm{X}}+\mathrm{H}_{2} \mathrm{O} & \text { fast (ii) } \\
\mathrm{X}+\left[\mathrm{RuCl}_{6}\right]^{3-} & \stackrel{\mathrm{K}_{3}}{\mathrm{X}^{\prime}} & \text { fast (iii) } \\
\mathrm{X}^{\prime}+\mathrm{H}_{2} \mathrm{O} & \mathrm{K}_{4} & \text { Promplex } & \text { slow (iv) }
\end{array}
$$

Figure 2. General mechanism for the $\mathrm{Ru}(\mathrm{III})$ catalyzed oxidation of secondary alcohols by BAT in acid solutions.

experimentally. The reactive $\mathrm{H}_{2} \mathrm{O}^{+} \mathrm{Br}$ species interacts with the substrate, alcohol, in a fast step (ii) to form the bromo intermediate $\mathrm{X}$ and $\mathrm{H}_{2} \mathrm{O}$. Furthermore, $\mathrm{X}$ reacts with the active catalyst species, $\left[\mathrm{RuCl}_{6}\right]^{3-}$, in a fast pre-equilibrium step (iii) to form the metal complex $\mathrm{X}^{\prime}$. The fractional order in $[\mathrm{Ru}(\mathrm{III})]$ supports the fast pre-equilibrium, step (iii), in the mechanism. Finally, $\mathrm{X}^{\prime}$ hydrolyzes in the slow, rate-limiting step forming end products.

Assuming the total effective concentration of $\mathrm{BAT},[\mathrm{BAT}]_{\mathrm{t}}=$ $[\mathrm{ArNHBr}]+{ }^{\prime}\left[\mathrm{H}_{2} \mathrm{O}^{+} \mathrm{Br}\right]+[\mathrm{X}]+\left[\mathrm{X}^{\prime}\right]$, the rate law given below can be derived.

$$
\begin{aligned}
& \frac{-\mathrm{d}[\mathrm{BAT}]}{\mathrm{dt}} \\
& =\frac{\mathrm{K}_{1} \mathrm{~K}_{2} \mathrm{~K}_{3} \mathrm{k}_{4}[\mathrm{BAT}]_{\mathrm{t}}[\text { alcohol }]\left[\mathrm{H}_{3} \mathrm{O}^{+}\right][\mathrm{Ru}(\mathrm{III})]}{\left[\mathrm{ArNH}_{2}\right]+\mathrm{K}_{1}\left[\mathrm{H}_{3} \mathrm{O}^{+}\right]+\mathrm{K}_{1} \mathrm{~K}_{2}\left[\mathrm{H}_{3} \mathrm{O}^{+}\right][\text {alcohol }]\left\{1+\mathrm{K}_{3}[\mathrm{Ru}(\mathrm{III})]\right\}}
\end{aligned}
$$

The rate law (Eq. (10)) is in agreement with the observed kinetic orders. The proposed scheme and the rate law are also supported by the experimental observations discussed below.

\section{Solvent Isotope Effect}

As expected for a $\mathrm{H}^{+}$catalyzed reaction, the rate increased in $\mathrm{D}_{2} \mathrm{O}$ medium. Since $\mathrm{D}_{3} \mathrm{O}^{+}$ion is a stronger acid than $\mathrm{H}_{3} \mathrm{O}^{+}$ion by a factor of $2-3$, a solvent isotope effect of this magnitude is to be expected. ${ }^{[2-29]} \mathrm{But}$ 
the observed inverse solvent isotope effect, $\mathrm{k}^{\prime}\left(\mathrm{D}_{2} \mathrm{O}\right) / \mathrm{k}^{\prime}\left(\mathrm{H}_{2} \mathrm{O}\right)=1.49$, probably shows that since the protonation is followed by hydrolysis in the ratelimiting step which involves $\mathrm{O}-\mathrm{H}$ bond scission, the normal kinetic isotope effect $\mathrm{k}_{\mathrm{H}} / \mathrm{k}_{\mathrm{D}}>1$ could counter balance the solvent isotope effect. Proton inventory studies in $\mathrm{H}_{2} \mathrm{O}-\mathrm{D}_{2} \mathrm{O}$ mixtures could shed light on the nature of the transition state. The variation of the rate constant for a reaction with the atom fraction of deuterium in a solvent mixture of $\mathrm{D}_{2} \mathrm{O}$ and $\mathrm{H}_{2} \mathrm{O}$, is given by the following form of the Gross-Butler equation: ${ }^{[30-31]}$

$$
\mathrm{k}_{\mathrm{n}}^{\prime} / \mathrm{k}_{0}^{\prime}=\prod^{\mathrm{TS}}\left(1-\mathrm{n}+\mathrm{n} \Phi_{\mathrm{i}}\right) / \prod^{\mathrm{RS}}\left(1-\mathrm{n}+\mathrm{n} \Phi_{\mathrm{j}}\right)
$$

where $\mathrm{k}_{n}^{\prime}$ is the rate constant in a mixed solvent containing a deuterium atom fraction, $n$, and $\mathrm{k}_{0}^{\prime}$ is the rate constant in pure $\mathrm{H}_{2} \mathrm{O}$; each $\prod$ represents a product of factors for the transition state (TS) or the reactant state (RS); and $\Phi_{i}$ and $\Phi_{j}$ are the isotopic fractionation factors for isotopically exchangeable hydrogen sites in the TS and RS, respectively. The right hand side numerator contains a term for each site in the TS that can exchange with the solvent whereas the denominator contains a term for each site in the reactants. Eq. (11) allows the calculation of fractionation factor of TS, if reactant fractionation factors are known. The fractionation factors for the reactants can be determined independently of kinetic studies by such methods as NMR and solubility. ${ }^{[30]}$ However, the amount of curvature of the proton inventory plot could reflect the number of exchangeable protons in the reaction. ${ }^{[30-32]} \mathrm{A}$ plot of $\mathrm{k}_{n}^{\prime}$ vs. $\mathrm{n}$ (Fig. 1, Table VI), in the present case, is a curve. A comparison with the standard curves ${ }^{[30-31]}$ indicates the involvement of proton or $\mathrm{H}-\mathrm{D}$ exchanges in the reaction sequence. A liner plot is indicative of a simple solvent isotope effect involving single exchangeable hydrogen in the TS, which is isotopically distinct from water (i.e., shows a change in $\Phi$ ). Hence, the participation of $\mathrm{H}^{+}$ions in the formation of the transition state is inferred.

\section{Structure-Reactivity Correlations}

The existence of a linear free-energy relationship (LFER) for the oxidation of secondary alcohols by BAT has been evaluated. Substituent effects have been correlated to rate parameters by Hammett for substitution in the aromatic ring systems. ${ }^{[31,32]}$ A similar correlation for aliphatic compounds has been given by Taft in terms of a polar substituent constant $\sigma^{*}$ (electronic effect) and a steric substituent constant $\mathrm{E}_{\mathrm{s}}$ (size effect). 


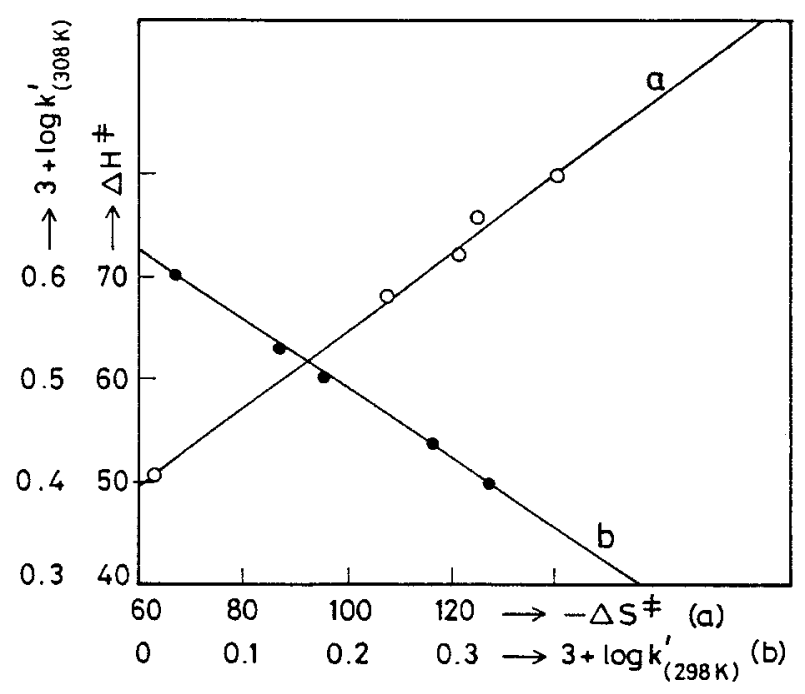

Figure 3. (a) Isokinetic plot of $\Delta \mathrm{H}^{\neq} v s . \Delta \mathrm{S}^{\neq}$for the oxidation of secondary alcohols by BAT. Experimental conditions are as in Table VIII; (b) Exner plot of $\log \mathrm{k}_{308 \mathrm{~K}}^{\prime}$ vs. $\mathrm{k}_{298 \mathrm{~K}}^{\prime}$ for the oxidation of secondary alcohols by BAT. Experimental conditions are as in Table VII.

Tests for the complete Taft equation as well as single parameter correlations with $\sigma^{*}$, and $\mathrm{E}_{\mathrm{s}}$ were made by plotting $\log \mathrm{k}^{\prime}$ vs. $\sigma^{*}, \log \mathrm{k}^{\prime} v s . \mathrm{E}_{\mathrm{s}}$ and $\log \left(\mathrm{k}^{\prime}-\mathrm{E}_{\mathrm{s}}\right)$ vs. $\sigma^{*}$. The following regression equations were obtained.

$$
\begin{array}{lc}
\log \mathrm{k}^{\prime}=-3.60 \sigma^{*}-2.82 & (\mathrm{r}=0.5892) \\
\log \mathrm{k}^{\prime}=-0.41 \mathrm{E}_{\mathrm{s}}-2.65 & (\mathrm{r}=0.4080) \\
\log \left(\mathrm{k}^{\prime}-\mathrm{E}_{\mathrm{s}}\right)=6.15 \sigma^{*}-2.90 & (\mathrm{r}=0.9147)
\end{array}
$$

Very poor correlations of the rate constant with $\sigma^{*}$ and $\mathrm{E}_{\mathrm{s}}$ [Eqs. (12) and (13)] indicate neither electronic nor steric factor affects the rate by itself. The negative value of the reaction constant $\left(\rho^{*}=-3.60\right)$ in Eq. (12) shows that electron-donating centers increase the rate of reaction. However, the good correlation between $\log \left(\mathrm{k}^{\prime}-\mathrm{E}_{\mathrm{s}}\right)$ and $\sigma^{*}$ [Eq. (14)] suggests that both electronic and steric effects are important. Devi et al. ${ }^{[10]}$ have observed a similar behavior for the oxidation of secondary alcohols by other oxidants. 


\section{Isokinetic Relationship}

It is seen from Table VIII that the activation energy is highest for the slowest reaction, indicating that the reaction is enthalpy controlled. This is verified by calculating the isokinetic temperature $(\beta)$ from the slope of a linear plot of $\Delta \mathrm{H}^{\neq}$vs. $\Delta \mathrm{S}^{\neq}$(Fig. 3a, $\mathrm{r}=0.9876$ ). The $\beta$ value of $350 \mathrm{~K}$, which is higher than the experimental range $(298-313 \mathrm{~K})$ used in the present study, implies that the substrate oxidation is enthalpy controlled. A further confirmation of the existence of isokinetic relationship was inferred from the Exner criterion ${ }^{[33]}$ by plotting $\log \mathrm{k}_{(308 \mathrm{~K})}$ vs. $\log \mathrm{k}^{\prime}{ }_{(298 \mathrm{~K})}$ which yielded a linear plot (Fig. 3b; $r=0.9902$ ). The value of $\beta$ was calculated from the equation, $\beta=\mathrm{T}_{1}(1-\mathrm{q}) /\left(\mathrm{T}_{1} / \mathrm{T}_{2}\right)-\mathrm{q}$, where $\mathrm{q}$ is the slope of the Exner plot; $\beta$ was found to be $354 \mathrm{~K}$. The fairly negative values of $\Delta \mathrm{S}^{\neq}$indicate the formation of a rigid, associative transition state with few degrees of freedom in each case (Table VIII).

\section{ACKNOWLEDGMENT}

One of us (R.R.) thanks the Principal and the Management of Jyothi Nivas College, Bangalore, India, for granting permission to perform graduate research in the Department of Post-Graduate Studies in Chemistry, Bangalore University, Bangalore, India.

\section{REFERENCES}

1. Campbell, M.M.; Johnson, G. Chloramine-T and Related N-Halogeno-N-metallo Reagents. Chem. Rev. 1978, 78, 65-79.

2. Banerji, K.K.; Jayaram, B.; Mahadevappa, D.S. Mechanistic Aspects of Oxidations by N-Metallo-N-haloarylsulfonamides. J. Sci. Ind. Res. 1987, 46, 65-76.

3. Mahadevappa, D.S.; Puttaswamy. Kinetics of Oxidation of Aliphatic Ketones with Bromamine-T in Acid Medium. Bull. Soc. Japan 1988, 61, 543-547.

4. Venkatesha, B.M.; Ananda, S.; Mahadevappa, D.S. Kinetics of Oxidation of Chloroacetic Acids by Bromamine- $\mathrm{T}$ in $\mathrm{HCl}$ Medium and Catalysis by $\mathrm{Ru}(\mathrm{III})$ Ion. Indian J. Chem. 1994, 33A, 128-135.

5. Waters, W.A. Mechanism of Oxidation of Organic Compounds; Methuen and Company: London, 1964, 49.

6. Wiberg, K.B. Oxidation in Organic Chemistry, Part A; Academic Press: New York, 1965, 142, 198, 247. 
7. Thiagarajan,V.; Venkatasubramanian, N. Kinetics and Mechanism of Oxidation of Secondary Alcohols with N-Bromosuccinimide. Indian J. Chem. 1970, 8, 809-814.

8. Natarajan, N.M.; Thiagarajan,V. Oxidation of Alcohols by NChlorosuccinimide - A Kinetic Study. Tetrahedron 1974, 30, 419-425.

9. Negi, S.C.; Banerji, K.K. Kinetics and Mechanism of Oxidation of Substituted Secondary Alcohols by N-Bromoacetamide in Acid Medium. Indian J. Chem. 1982, 21B, 846-848.

10. Devi, J.; Kothari, S.; Banerji, K.K. Kinetics and Mechanism of the Oxidation of Secondary Alcohols by Pyridinium Hydrobromide Perbromide. J. Indian Chem. Soc. 1996, 73, 243-246.

11. Ramachandra, H.; Rangappa, K.S.; Mahadevappa, D.S.; Made Gowda, N.M. Oxidation of Substituted Phenethyl Alcohols by Sodium-N-chloro-p-toluenesulphonamide: A Kinetic Study. Monatsh. Chem. 1996, 127, 241-255.

12. Nair, C.G.R.; Kumari, R.L.; Indresenan, P. Bromamine-T as a New Oxidimetric Titrant. Talanta 1978, 25, 525-527.

13. Rangappa, K.S.; Mahadevappa, D.S.; Gowda, B.T.; Made Gowda, N.M. Some Analytical Applications of Aromatic Sulfonyl Haloamines: Determination of Thiocyanate and Cyanide Ions in Metal Complexes and Salts and Thiosemicarbazide in Metal Complexes with Bromamine-T. Microchem. J. 1981, 26, 375-386.

14. Vogel, A.I. Text Book of Practical Organic Chemistry, 5th Edn.; ELBS: London, 1989, 1257, 1336.

15. Mahadevappa, D.S.; Ananda, S.; Made Gowda, N.M.; Rangappa, K.S. Oxidation of Methionine by Sodium N-Chlorotoluene-p-sulphonamide in Aqueous Solution: A Kinetic Study. J. Chem. Soc. Perkin Trans. II 1985, 39-43.

16. Bishop, E.; Jennings, V.J. Titrimetric Analysis with Chloramine-T: The Status of Chloramine-T as a Titrimetric Reagent. Talanta 1958, 1, 197-199.

17. Hardy, F.F.; Johnston, J.P. The Interaction of N-Bromo-N-Sodiobenzenesulphonamide (Bromamine-B) with $p$-Nitrophenoxide Ion. J. Chem. Soc. Perkin Trans. II 1973, 742-745.

18. Morris, J.C.; Salazar, J.A.; Wineman, M.A. Equilibrium Studies on Chloro Compounds: The Ionization Constant of N-Chloro-p-toluenesulfonamide. J. Amer. Chem. Soc. 1948, 70, 2036-2041.

19. Backhouse, J.R.; Dwyer, F.D.; Shales, N. Chemistry of Ru(IV) Potential of the Quadrivalent/Trivalent $\mathrm{Ru}$ Couple in $\mathrm{HCl}$. Proc. Roy. Soc. 1950, 83, 146-155.

20. Cotton, F.A.; Wilkinson, G.; Gaus, P.L. Basic Inorganic Chemistry, 3rd Edn.; John Wiley and Sons, Inc.: New York, 1995, 600. 
21. Davfokratova, T. Analytical Chemistry of Ruthenium; Academy of Sciences: USSR, 1963, 54, 71, 97.

22. Griffith, W.P. The Chemistry of Rare Platinum Metals; Inter Science: New York, 1967, 141.

23. Singh, B.; Singh, N.B.; Saxena, B.B.L. Mechanism of Ru(III) Catalysis in Bromamine-T Oxidation of Some Primary Alcohols in Acidic Medium. J. Ind. Chem. Soc. 1984, 61, 319-326.

24. Singh, B.; Singh, P.K.; Singh, D. Ru(III) Catalysis in N-Bromoacetamide Oxidation of Ethyleneglycol and Glycerol: A Kinetic and Mechanistic Study. J. Mol. Cat. 1988, 78, 207-212.

25. Gopalakrishnan, G.; Hogg, J.L. Kinetic and Mechanistic Studies of the N-Bromosuccinimide-Promoted Oxidative Decarboxylation of Glycine, DL-Alanine, and DL-Valine. J. Org. Chem. 1985, 50, $1206-1212$.

26. Chappelle, E.W.; Luck, J.M. The Decarboxylation of Amino Acids, Proteins, and Peptides by N-Bromosuccinimide. J. Biol. Chem. 1957, 229, 171-179.

27. Stevenson, G.W.; Luck, J.M. The Bromodecarboxylation of Amino Acids: Formation of Nitriles. J. Biol. Chem. 1961, 236, 715-717.

28. Collins, C.J.; Bowman, N.S. Isotope Effects in Chemical Reactions; Van Nostrand-Reinhold: New York, 1970, 267.

29. Amis, E.S. Solvent Effects on Reaction Rates and Mechanisms; Academic Press: New York, 1966.

30. Albery, W.J.; Davies, M.H. Mechanistic Conclusions from the Curvature of Solvent Isotope Effects. J. Chem. Soc. Faraday. Trans. 1972, 68, 167-173.

31. Isaacs, N.S. Physical Organic Chemistry; John Wiley and Sons, Inc.: New York, 1987, 275.

32. Gillion, R.D. Introduction to Physical Organic Chemistry; AddisonWesley: London, 1970, 156-168, 264.

33. Exner, O. On the Enthalpy-Entropy Relationship. Czech. Chem. Commun. 1964, 29, 1094-1114.

Received August 21, 2001

Referee I: K. Moedritzer

Accepted May 10, 2002

Referee II: D. T. Esterline 